\title{
Wave power boosted in UK energy hand out
}

LAST week the UK Department of Energy (DoEn) produced its longawaited reply to two reports of the House of Commons Select Committee on Science and Technology on alternative energy-and the Severn Barrage. In the guise of a White Paper called 'The development of alternative sources of energy', the reply announces the allocation of $£ 4.5$ million for R\&D on wave, wind and geothermal energy and the provisional allocation of $£ 1.5$ million for further studies to assess tidal barrage schemes in the Severn estuary. A Severn Barrage committee under the chairmanship of Sir Hermann Bondi, Chief Scientist in the department, is to be set up to advise the DoEn on which studies it should spend its money.

The White Paper's recommendations are broadly in line with those set out in the two select committee reports. They acknowledge that alternative energy sources should be developed with "urgency and determination". The White Paper goes on to say that because these sources are at an early stage of their development, "the limitation to making faster progress is not the level of funding but the state of the technology involved". According to Sir Hermann Bondi however, alternative energy sources will become "hungrier and hungrier" as their development progresses and the DoE is "to keep the level of funding under close review and be prepared, in the light of progress, to make further sums available for the more promising lines of development".

The lion's share of the $£ 4.5$ million is to be spent on wave power, the alternative energy source with the greatest potential for large scale electrical generation in the UK. $£ 2.9$ million is to be added to the $£ 2.5$ million programme due for completion in October. Half of it will go to support device development, $£ 300,000$ will be used to support collaborative work with other countries (especially Japan) through the International Energy Agency and the remainder will be used to tackle the environmental and engineering problems applicable to all types of device.

Wave power is a "high risk, high reward" energy source according to Sir Hermann Bondi. If developed successfully, it could harness the energy in the particularly heavy seas around Britain with the advantage of a supply matched to the demand (the heaviest seas, and hence the most energy, occur during the winter). However, the engineering problems are formidable and the economics of a technically feasible device would be difficult to work out. Nevertheless tenth-scale models of two devices have already been built and the DoE White Paper says that subject to satisfactory progress expenditure will increase over the next three or four years and a single device will be identified for concentrated development. The programme is to be reviewed each spring.
Research on wind power comes in for for an additional $£ 806,000$. $£ 341,000$ is to be spent during the next year on design and compenent testing of a $60 \mathrm{~m}$ diameter, 3.7 MW commercialsize prototype 'aerogenerator' (the new word for windmills). If this stage is successful, the DoEn will start a three year programme costing about $£ 2$ million to build and test a prototype. The remaining $£ 465,000$ will be spent over the next two years on development of a vertical axis aerogenerator and wind energy from lowland and off-shore sites.

Although geothermal energy is not likely to be providing energy in the UK until after other alternative sources have been developed, the DoEn has allocated $£ 856,000$ for further geological, geophysical and hydrogeological surveys and studies of heat flow. The solar energy programme, however, does not come in for any of the hand out. It was increased to $£ 6$ million last year when an extra $£ 3.6$ million was made available and the DoEn feels that no other measures are needed at present to further stimulate industry with its development work. However the White Paper does not go along with the select committee's recommendation that funds should be available to encourage installation of solar water heaters. The current state of the technology does not support this case, it says.

Judy Redfearn

\section{Bacterium makes insulin}

THE synthesis of mammalian insulin by a bacterial cell, one of the most canvassed examples of the benefits of gene transplantation techniques, is at last a reality. In a lecture at the University of Chicago last week Professor Walter Gilbert of Harvard University reported the construction in his laboratory of bacteria producing small quantities of rat proinsulin, the immediate precursor to biologically active insulin.

The genetic information for the rat proinsulin was inserted into a bacterial plasmid which encodes the bacterial enzyme penicillinase. The completed nucleotide sequence of this plasmid is known, and the modified plasmid was resequenced after insertion of the proinsulin DNA to check that the inserted fragment was in the correct orientation and reading frame to be translated as part of the penicillinase protein.

Penicillinase was chosen as the 'carrier' for the foreign protein as it is one of the proteins naturally secreted from the bacterial cell. When the modified plasmid was introduced into a suitable strain of Escherichia coli the bacterium synthesised minute amounts, around 100 molecules per cell, of the modified protein from which the proinsulin could be recovered.

The idea of inducing bacteria to synthesise foreign proteins by hiding them in a natural bacterial protein was first used successfully to synthesise the brain hormone somatostatin last year. In that case the somatostatin coding sequences were chemically synthesised; in this case the proinsulin DNA was apparently copied from the abundant insulin messenger RNA produced by an insulin-producing rat tumour.

\section{MPs seek to see Shcharanskii}

Anatolil Shcharanskii (right), the Moscow cyberneticist and human rights activist, was arrested in March 1977 for alleged subversive activities and has since been held incommunicado in Lefortovo prison.
The International Committee for the defence of Anatolii Shcharanskii, which includes members of both houses of Parliament and representatives of the arts and professions, last Thursday issued a statement calling for his release. The committee is to seek visas for its co-chairmen MPs John Gorst (Con), Helene Hayman (Lab), Russell Johnston (Lib) to visit Shcharanskii. In the event of a trial they will seek to send a delegation from both houses of Parliament to observe the proceedings in accordance with international precedent.

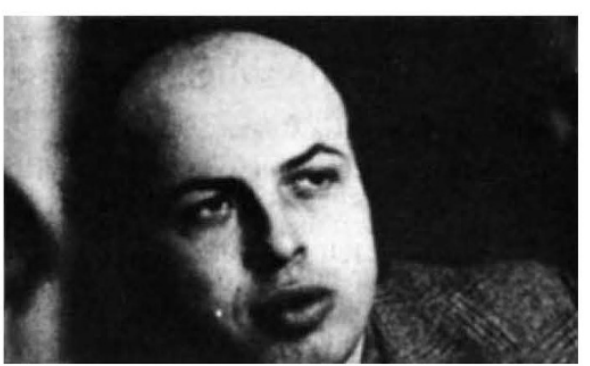

